\begin{tabular}{|c|c|c|c|}
\hline Substance & $\begin{array}{l}\text { Colour with diazot- } \\
\text { ized sulphanilic acid }\end{array}$ & $\boldsymbol{R}_{F^{\prime}}$ & S.D. \\
\hline $\begin{array}{l}A \text { Phenol } \\
B \text { p-Hydroxybenzoic acid } \\
C \text { m-Hydroxybenzoic acid } \\
D \text { Salicylic acid } \\
E \text { Catechol } \\
F \text { Protocatechuic acid } \\
G \text { Resorcinol } \\
H \text { } \\
I \text {-Resorcylic acid } \\
J \text { Hydroquinone } \\
K \text { Gentisic acid } \\
L \text { Pyrogallol } \\
\text { Pyrogallol carboxylic } \\
M \text { Gallic acid } \\
N \text { Hydroxyquinol } \\
O \text { Hydroxyquinol carb- } \\
\text { oxylic acid } \\
P \text { Phloroglucinol } \\
Q \text { Tannic acid } \\
\text { Guiacol } \\
\text { Thymol } \\
\alpha \text {-Naphthol } \\
\beta \text {-Naphthol }\end{array}$ & $\begin{array}{l}\text { Deep yellow } \\
\text { ",", } \\
\text { Pale yellow } \\
\text { Reddish-brown } \\
\text { Brown ," } \\
\text { Colourless } \\
\text {,", } \\
\qquad,, \\
\text { Brown } \\
\text { Orange } \\
\text { Colourless } \\
\text { Orange } \\
\text { Yellowish-brown } \\
\text { Brownish-red } \\
\text { Orange }\end{array}$ & $\begin{array}{l}0.97 \\
0.85 \\
0.74 \\
0.65 \\
0.96 \\
0.74 \\
0.97 \\
0.55 \\
0.96 \\
0.51 \\
0.94 \\
0.71 \\
0.43 \\
0.48 \\
0.45 \\
0.96 \\
0.99\end{array}$ & $\begin{array}{l}0.01 \\
0.02 \\
0.01 \\
0.02 \\
0.00 \\
0.01 \\
0.00 \\
0.03 \\
0.01 \\
0.01 \\
0.01 \\
0.04 \\
0.03 \\
0.04 \\
0.01 \\
0.02 \\
0.01\end{array}$ \\
\hline
\end{tabular}

before colouring it will show if gentisic acid is present, as this substance gives a vivid blue fluorescence.

The chromatogram shows the position of the main compounds tested, but for photographic purposes it had to be somewhat overloaded-this accounts for the diffuse nature of some of the spots. All phenols (including naphthols and phenolic aldehydes) have similar high $R_{F^{\prime}}$ values, but the method will, for example, separate the three mono-hydroxy benzoic acids from one another and from phenols. Anomalous $R_{F^{\prime}}$ values appear to characterize hydroxyquinol and tannic acid; in both cases some decomposition at the point of deposition seems to occur.

$$
\begin{aligned}
& \text { R. A. Evans } \\
& \text { W. H. ParR } \\
& \text { W. C. Evans }
\end{aligned}
$$

Biochemical Laboratories, Department of Animal Health, University College of Wales,

$$
\begin{gathered}
\text { Aberystwyth. } \\
\text { May } 2 .
\end{gathered}
$$

'Consden, R., Gordon, A. H., and Martin, A. J. P., Biochem. J., 38, 224 (1944).

${ }^{2}$ Consden, R., Nature, 162, 359 (1948).

${ }^{3}$ Bate-Smith, E. C., Biochem. J., 43, xlix (1948).

" Evans, R. A., Parr, W. H., and Evans, W. C., Biochem. J., 44, vii (1949).

${ }^{5}$ Williams, R. J., and Kirby, H., Science, 107, 481 (1948).

\section{Entomology as a Career}

EVERY generation produces a number of young naturalists, some of whom seek a career in which they can follow their interests. Of these a proportion have in the past turned to entomology, and it is to be hoped that they will continue to do so in the future. The proceedings of a recent conference held in London, the Second International Congress of Plant Protection, and a remark in the presidential address to the Society of Chemical Industry ${ }^{1}$ tend to support the view - much fostered by interested parties at the present time-that entomology in its applied aspects is no longer the province of the biologist, but is rapidly becoming, if it has not already become, that of the chemist and physicist. Sir David Rivett, in the address referred to, said, "When for example one approaches a problem of pest insect control, may it not well be that a physicist, aided by a mathematician and guided by a chemist, will prove of more value than any other worker?"
If this point of view becomes widely accepted, as it is in danger of being, then doubtless it will tend to divert from the profession those who delight in handling and studying living things, thus leaving the field to followers of the 'dead' sciences.

Nothing could be further from the truth than that knowledge leading to the better control of injurious insects is to be sought in the main from chemists. While they are necessary auxiliaries to entomologists in this field and are to be congratulated on recent striking contributions in the field of insecticides, it is from biologists, more especially ecologists, that future additions to needed knowledge concerning insect pests must be sought, knowledge on which the chemist's contribution must depend and without which, in many instances, it can be of no account.

Frequently a study of an insect pest in relation to its environment has yielded information enabling simple and inexpensive measures of control to be applied, such as may be brought about by a modification of farming practice. Such measures, when available, are always preferable to chemical control ones, which are never cheap and sometimes accomplish harmful, unforeseen results.

It is probable that at the moment more openings exist in a varied field for trained, young biologists than has ever been the case previously. Those who are drawn to the study of insects need have no fear that in becoming entomologists they may be entering a dying profession, for the study of living insects will always remain the basic approach to problems of insect control. Entomology will thus, in the future, as in the past, continue to ofier an interesting career to followers of the 'live' sciences.

Ministry of Agriculture and Fisheries,

$$
\text { J. W. Evans }
$$

Infestation Control Division, London, W.C.

${ }^{1}$ Chemistry and Industry, 30, 527 (1949).

\section{The Dry Crossing of the Nile}

In Nature of November 6, 1937, p. 811, and September 24,1938 , p. 576 , letters were published on the 'Dry Crossing of the Nile'. This crossing was a mass of floating vegetation where the river is 80 yards across, and the 'bridge' was about 250 yards from its upstream to its downstream edge. It was sufficiently strong for elephants to cross. A photograph taken by Dr. Alexander Cruickshank, from whom these particulars were obtained, was reproduced. My son, Colonel F. O. Cave, has obtained further particulars from Mr. Siricio Iro, a member of the Sudan Legislative Assembly, whose home is in the neighbourhood of the crossing, from which it appears that grass, trees and vegetation, brought down by floods, are held up by a large rock in mid-stream which acts as a foundation for the bridge, which apparently lasts until the vegetation over the rock has rotted. The last two bridges remained intact for eight and ten years respectively, the last one being washed away in 1946. Further local information indicates that the bridge started to reform in July 1948 but was washed away again by very heavy floods in the following October. A Sudan official who walked along the banks of the Nile from Nimule to Juba in March 1949 saw no sign of a dry crossing.

Stoner Hill,

C. J. P. CAVE

Petersfield. 